\title{
Recovery of Ag, Au, and Pt from Printed Circuit Boards by Pressure Leaching
}

\author{
Guadalupe Martinez-Ballesteros ${ }^{1}$, Jesus Leobardo Valenzuela-García ${ }^{1, *} \mathbb{0}$, Agustin Gómez-Alvarez ${ }^{1}$, \\ Martin Antonio Encinas-Romero ${ }^{1}$, Flerida Adriana Mejía-Zamudio ${ }^{1}$, Aaron de Jesús Rosas-Durazo ${ }^{2}$ \\ and Roberto Valenzuela-Frisby ${ }^{3}$
}

check for updates

Citation: Martinez-Ballesteros, G.; Valenzuela-García, J.L.;

Gómez-Alvarez, A.; Encinas-Romero,

M.A.; Mejía-Zamudio, F.A.;

Rosas-Durazo, A.d.J.;

Valenzuela-Frisby, R. Recovery of Ag, $\mathrm{Au}$, and Pt from Printed Circuit Boards by Pressure Leaching. Recycling 2021, 6, 67. https:// doi.org/10.3390/recycling6040067

Academic Editor: Ana Paula Paiva

Received: 22 August 2021

Accepted: 7 October 2021

Published: 13 October 2021

Publisher's Note: MDPI stays neutral with regard to jurisdictional claims in published maps and institutional affiliations.

Copyright: (c) 2021 by the authors. Licensee MDPI, Basel, Switzerland. This article is an open access article distributed under the terms and conditions of the Creative Commons Attribution (CC BY) license (https:// creativecommons.org/licenses/by/ $4.0 /)$.
1 Department of Chemical Engineering and Metallurgy, University of Sonora, Hermosillo 83000, Mexico; guadalupe.martinezballesteros@gmail.com (G.M.-B.); agustin.gomez@unison.mx (A.G.-A.); martin.encinas@unison.mx (M.A.E.-R.); flerida.mejia@unison.mx (F.A.M.-Z.)

2 Department Biomedical Engineering, Unidad Hermosillo, Sonora State University, Hermosillo 83100, Mexico; a.rosas.durazo@gmail.com

3 Retroworks of México S.A. of C.V., Fronteras 84320, Mexico; rmababi@gmail.com

* Correspondence: jesusleobardo.valenzuela@unison.mx; Tel.: +52-662-847-6298

\begin{abstract}
Reclamation of printed circuit boards (PCBs) to recover metals is gaining growing attention due to minerals being non-renewable resources. Currently, metals extraction from PCBs through an efficient and green method is still under investigation. The present investigation concerns the recycling of printed circuit boards using hydrometallurgical processes. First, the basic metals $(\mathrm{Cu}, \mathrm{Ni}, \mathrm{Zn}$ and Fe) were separated using a sulfuric acid solution at moderate temperatures. The remaining solids were characterized by SEM-EDS, whereby a high content of precious metals ( $\mathrm{Au}, \mathrm{Ag}$ and $\mathrm{Pt}$ ) was observed. In the second stage, solids were leached with a solution of $\mathrm{HCl}$ and $\mathrm{NaClO}$ in a 1-L titanium reactor with varied oxygen pressure $(0.2,0.34$ and $0.55 \mathrm{MPa})$, temperature $\left(40,50\right.$ and $\left.80^{\circ} \mathrm{C}\right)$ and concentration of $\mathrm{HCl}\left(2\right.$ and $4 \mathrm{M}$ ), obtaining extractions above $95 \%$ at $[\mathrm{HCl}]=4 \mathrm{M}, \mathrm{P}=0.34 \mathrm{MPa}$ and $\mathrm{T}=40^{\circ} \mathrm{C}$. The extraction increased depending on the concentration of $\mathrm{HCl}$. Eh-pH diagrams for $\mathrm{Ag}-\mathrm{Cl}-\mathrm{H}_{2} \mathrm{O}$, $\mathrm{Au}-\mathrm{Cl}-\mathrm{H}_{2} \mathrm{O}$ and $\mathrm{Pt}-\mathrm{Cl}-\mathrm{H}_{2} \mathrm{O}$ were constructed to know the possible species in the solution.
\end{abstract}

Keywords: pressure leaching; precious metals; printed circuit boards; recycling

\section{Introduction}

Technology has recently advanced by leaps and bounds, and the production of electronic and electrical equipment (EEE) increases day by day. In a very short period, the most innovative of modern devices become obsolete at a faster rate than in the past. Therefore, the increase in waste originating from electrical and electronic equipment (WEEE) traces back to both private homes and professional users [1,2]. These materials are not properly treated when they reach the end of their useful life because they are sent untreated to landfills. Equipment components (heavy metals, plastics, polymers, ceramics, etc.) represent an important contamination source with severe ecosystem and health ramifications. Additionally, in recent years, concern has been growing for the environment worldwide [3]. Due to the increasing amounts of electronic waste generated in recent years, natural resources have depleted. Researchers have found it necessary to study various ways to recycle these wastes; as a result, their harmfulness has been reduced. Electronic waste is also a rich source of metals (basic, precious and rare earth) [3,4]. Printed circuit boards (PCBs) are the main components of electronic waste and are the primary source of metals of interest [5]. A PC's printed circuit board can contain up to $20 \%$ copper, $250 \mathrm{~g} /$ ton of gold and $110 \mathrm{~g} /$ ton of palladium [6]. These metals can be recovered via metallurgical processes, preferably via the hydrometallurgical route. With the pyrometallurgical route, very high temperatures are required to achieve incineration due to the properties of the base material of the PCBs (Bakelite, fiberglass resin, reinforced glass, ceramics or polymers). These 
materials can withstand high temperatures. In addition, when they are incinerated, they generate dibenzo-p-dioxins and dibenzofurans (PCDD/Fs) and polybrominated diphenyl ethers (PBDD/Fs) [7-10].

The composition of WEEEs is much more complex than that of minerals, due to the physical and chemical characteristics of these materials; this permits the recovery of valuable metals being carried out in more stages for an efficient and environmentally sound processing of WEEE [11,12]. One way to recycle these is through hydrometallurgical processes since these do not generate as many gases and can separate metals selectively, due to the composition of waste PCBs, including plenty of toxic materials such as heavy metals, polyvinyl chloride (PVC) plastic and brominated flame retardants (BFR) [12]. Several researchers have studied the recovery of precious metals from WEEE. Gamez et al. studied the recovery of $\mathrm{Au}, \mathrm{Ag}, \mathrm{Pd}$ and $\mathrm{Rb}$ from discarded cell phone printed circuits. They used the cyanidation technique to extract $\mathrm{Au}, \mathrm{Ag}$ and $\mathrm{Pd}$ by leaching with potassium hydroxide $(\mathrm{KOH})$, nitric acid $\left(\mathrm{HNO}_{3}\right)$, sulfuric acid $\left(\mathrm{H}_{2} \mathrm{SO}_{4}\right)$ and sodium chloride $(\mathrm{NaCl})$. Recoveries of $95 \% \mathrm{Au}, 82 \% \mathrm{Ag}$ and $42 \% \mathrm{Pd}$ were obtained [13]. Birloaga et al. carried out tests to recover $\mathrm{Au}$ by thiolation using $20 \mathrm{~g} / \mathrm{L} \mathrm{CS}\left(\mathrm{NH}_{2}\right)_{2}, 6 \mathrm{~g} / \mathrm{L} \mathrm{Fe}^{3+}$ and $10 \mathrm{~g} / \mathrm{L} \mathrm{H}_{2} \mathrm{SO}_{4}$, with stirring at $600 \mathrm{rpm}$; when performed at room temperature, $82 \%$ of the $\mathrm{Au}$ in the material dissolved [14]. Jadhav and Hocheng investigated the recovery of metals $(\mathrm{Cu}, \mathrm{Zn}, \mathrm{Sn}, \mathrm{Ni}$, $\mathrm{Pb}, \mathrm{Fe}, \mathrm{Ag}, \mathrm{Au}$ and $\mathrm{Pd}$ ) by leaching waste from $\mathrm{PCBs}$ via different leaching agents $(\mathrm{HCl}$, $\mathrm{HNO}_{3}, \mathrm{H}_{2} \mathrm{SO}_{4}, \mathrm{C}_{2} \mathrm{H}_{4} \mathrm{O}_{2}$ and $\mathrm{C}_{6} \mathrm{H}_{8} \mathrm{O}_{7}$ ). They designed a metal recovery process using one of these reagents, obtaining good results when $\mathrm{HCl}$ was used (taking $22 \mathrm{~h}$ to dissolve $100 \%$ of the studied metals) [15]. Torres and Lapidus studied the leaching of Au by thiourea at room temperature after pre-treatment for the elimination of $\mathrm{Cu}$ with inorganic acids $(\mathrm{HCl}$, $\mathrm{HNO}_{3}$ and $\mathrm{H}_{2} \mathrm{SO}_{4}$ ), extracting more than $90 \% \mathrm{Au}$ [16]. Lei et al. studied the extraction of $\mathrm{Pt}$ and $\mathrm{Au}$ from anode-refining sludge derived from copper anodes via a roasting process followed by leaching with $\mathrm{H}_{2} \mathrm{SO}_{4}$ and sodium chloride $(\mathrm{NaCl})$ as the chlorinating agent, recovering around $95 \%$ of $\mathrm{Pt}$ and more than $98 \%$ of $\mathrm{Au}$ [17].

$\mathrm{HCl}$ can be used as a leaching agent because it can dissolve precious metals, allowing for their recovery. Chlorination was widely applied in the 19th century, before the introduction of cyanidation, for the treatment of minerals containing fine gold and gold with sulfides, which could not be recovered by gravimetric concentrating. Chloride media has also been applied in electroplating processes since the early 19th century. Although chlorine-chloride media is no longer used to leach primary minerals, several processes have been proposed to treat refractory or semi-refractory minerals. As an alternative to cyanide, it has also been applied for the pre-treatment oxidation of some carbonaceous refractory minerals [18].

In the present investigation, the recovery of precious metals from PCBs was studied. Due to the complexity of the material and the presence of metallic alloys, hydrochloric acid was used as the leachate and sodium and oxygen hypochlorite as the oxidants. The thermodynamic characteristics of the leaching of metals and the effects of pressure and temperature on the extraction of $\mathrm{Au}, \mathrm{Ag}$ and $\mathrm{Pt}$ are discussed using SEM-EDS and chemical analysis.

\section{Materials and Methods}

\subsection{Materials}

The materials were provided by Retroworks de México S.A. de C.V., located in Fronteras, Sonora, Mexico. The concentration of metals printed circuit boards (PCBs) was determined by the atomic absorption spectroscopy technique (Perkin Elmer model AAnalyst 400 atomic absorption equipment, PerkinElmer Inc, Waltham, MA, USA), and the metals concentration PCBs are shown in Table 1. In solutions, the $\mathrm{pH}$ and REDOX potential were analyzed using a Thermo Scientific Orion Star A111 pH benchtop meter (Thermo Fisher Scientific Inc, Waltham, MA, USA); this allowed us to construct a thermodynamic diagram of $\mathrm{Eh}-\mathrm{pH}$ and determine the species in solution. The solid residues were analyzed to determine the characteristics of the material after leaching by scanning electron 
microscopy and energy dispersive spectroscopy (SEM-EDS), using a Thermo Scientific Phenom Pro-X (Thermo Fisher Scientific Inc, Waltham, MA, USA). The Pourbaix Eh-pH diagrams were calculated using the HSC 6.0 program for each metal-electrolyte system under corresponding conditions. The chemicals $\left(\mathrm{HCl}_{(\mathrm{l})}(37 \%), \mathrm{NaClO}_{(\mathrm{l})}(13 \%), \mathrm{NaCl}_{(\mathrm{s})}\right.$, $\left.\mathrm{O}_{2(\mathrm{~g})}\right)$ were of analytical grade $(\geq 99.9 \%)$.

Table 1. Chemical composition of printed circuit boards.

\begin{tabular}{ccccccccc}
\hline Metal & Ag & Au & Pt & Pd & Cu & Zn & Ni & Fe \\
\hline Content & $170(\mathrm{~g} / \mathrm{t})$ & $220(\mathrm{~g} / \mathrm{t})$ & $2(\mathrm{~g} / \mathrm{t})$ & $1.2(\mathrm{~g} / \mathrm{t})$ & $13.14 \%$ & $0.02 \%$ & $4 \%$ & $4.9 \%$ \\
\hline
\end{tabular}

\subsection{Methods}

The PCBs were subjected to a treatment with sodium hydroxide $(10 \mathrm{M})$ to remove the epoxy material, for $24 \mathrm{~h}$, and later, the PCBs were rinsed with water to remove the sodium hydroxide [15]. The epoxy material was removed so that it would not interfere with the leaching of metals. Then, they were cut into pieces of approximately $2 \times 2 \mathrm{~cm}$ for further pulverization at a particle size of $-177 \mu \mathrm{m}$. In the first stage, the dissolution of the basic metals was carried out by leaching with sulfuric acid $\left(\mathrm{H}_{2} \mathrm{SO}_{4}\right) 2 \mathrm{M}$, pressure of $0.55 \mathrm{MPa}$ and a temperature of $90{ }^{\circ} \mathrm{C}$, obtaining recoveries greater than $91 \% \mathrm{Zn}$ and $98 \% \mathrm{Cu}$ and $\mathrm{Ni}$. The chemical compositions (Table 2) of the solids after treatment with $\mathrm{H}_{2} \mathrm{SO}_{4}$ were determined by the atomic absorption spectroscopy technique (AAS).

Table 2. Chemical composition of printed circuit boards after pretreatment with $\mathrm{H}_{2} \mathrm{SO}_{4}$.

\begin{tabular}{ccccccccc}
\hline Metal & Ag & Au & Pt & Pd & Cu & Zn & Ni & Fe \\
\hline Content & $280(\mathrm{~g} / \mathrm{t})$ & $320(\mathrm{~g} / \mathrm{t})$ & $28(\mathrm{~g} / \mathrm{t})$ & $12(\mathrm{~g} / \mathrm{t})$ & $0.13 \%$ & $0.0016 \%$ & $0.004 \%$ & $0.43 \%$ \\
\hline
\end{tabular}

In the second stage, the precious metal leaching was carried out with hydrochloric acid $(\mathrm{HCl})$ as a leaching agent, using the oxidants $0.067 \mathrm{M}$ sodium hypochlorite $(\mathrm{NaClO})$ and $0.017 \mathrm{M}(\mathrm{M}=$ moles $/ \mathrm{L})$ sodium chloride $(\mathrm{NaCl})$, present at $20 \%$ solids, as well as tap water. We added the pulp to the Titanium PARR Reactor (capacity $1 \mathrm{~L}$ ) and processed it at $600 \mathrm{rpm}$ for $2 \mathrm{~h}$; varying the concentration of $\mathrm{HCl}(2 \mathrm{M}$ and $4 \mathrm{M})$, the oxygen partial pressure (0.2, 0.34 and $0.55 \mathrm{MPa})$, and the temperature $\left(40,55\right.$, and $\left.70{ }^{\circ} \mathrm{C}\right)$, the pressure inside the reactor remained constant due to the injection of oxygen and the temperature due to the heating jacket of the titanium PARR reactor. After the established contact time, the solution was filtered to separate the solid and the liquid. The solutions obtained were analyzed by the atomic absorption spectroscopy technique (AAS) to determine their metallic concentration, while solid residues were analyzed to determine the characteristics of the material by SEM-EDS. The flowsheet of metals selective leaching from PCBs is given in Figure 1.

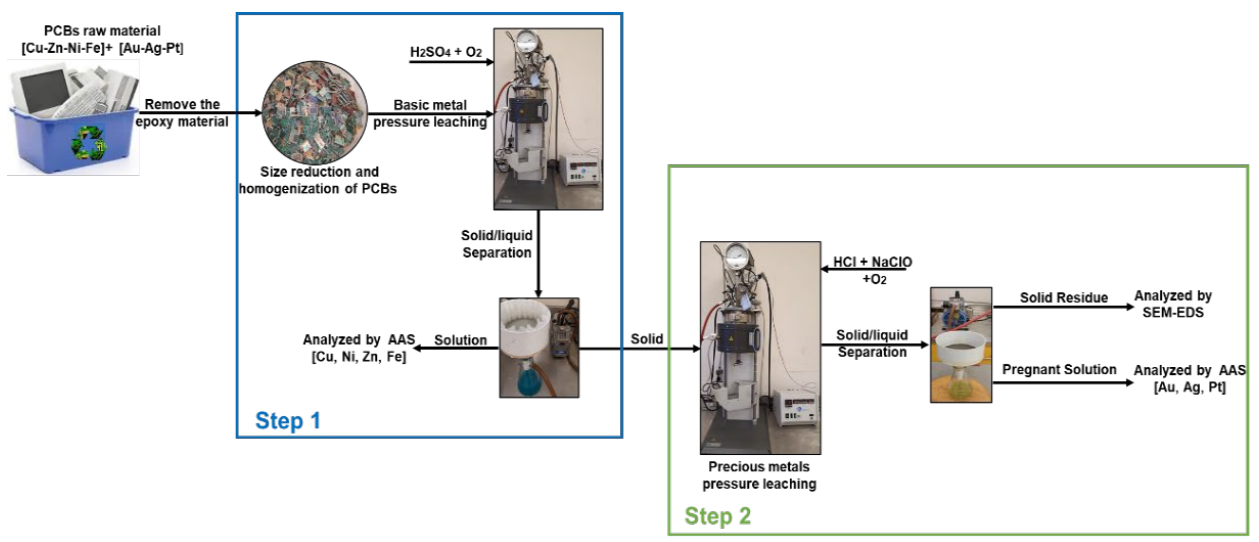

Figure 1. Flowsheet of metals selective leaching from PCBs. 


\section{Results}

\subsection{Pressure Leaching}

3.1.1. Silver

Figure 2 shows the effect on silver leaching when $\mathrm{HCl}$ concentration (2 and $4 \mathrm{M}$ ), pressure $(0.2,0.34$, and $0.55 \mathrm{MPa})$ and temperature are varied $\left(30,55\right.$, and $\left.70^{\circ} \mathrm{C}\right)$. Figure $2 \mathrm{~A}$ shows Ag extraction (\%) as a function of pressure $(\mathrm{MPa})$ at different temperatures and $2 \mathrm{M}$ $\mathrm{HCl}$. The best leaching conditions were reached when conditions of $40^{\circ} \mathrm{C}$ and $0.34 \mathrm{MPa}$ were used. The extraction of Ag under these conditions was above $50 \%$. Figure $2 \mathrm{~B}$ shows the graph of $\mathrm{Ag}$ extraction (\%) as a function of pressure and temperature at $4 \mathrm{M} \mathrm{HCl}$. An efficiency of Ag extraction greater than $98 \%$ was obtained when a temperature of $40{ }^{\circ} \mathrm{C}$ and a pressure of $0.34 \mathrm{MPa}$ were used.
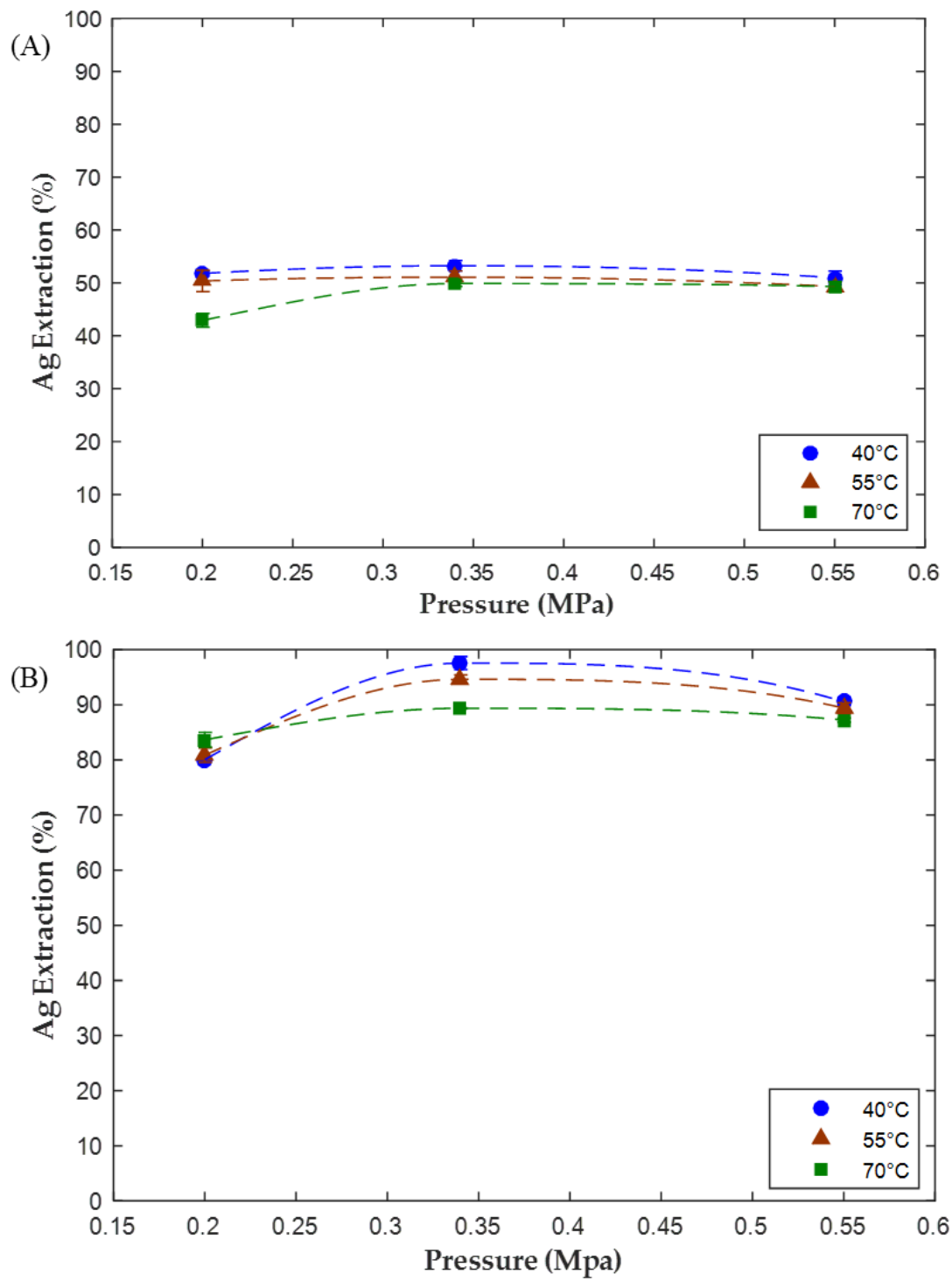

Figure 2. Ag extraction (\%) as a function of pressure (MPa), at different temperatures, $(\mathbf{A})$ at $2 \mathrm{M} \mathrm{HCl}$ and (B) $4 \mathrm{M} \mathrm{HCl}$.

\subsubsection{Gold}

Figure 3 shows the gold leaching when the concentration of $\mathrm{HCl}(2 \mathrm{M}$ and $4 \mathrm{M})$, the pressure $(0.2,0.34$ and $0.55 \mathrm{MPa})$ and the temperature $\left(40,55\right.$, and $\left.70{ }^{\circ} \mathrm{C}\right)$ were varied. Figure $3 \mathrm{~A}$ shows Au extraction (\%) as a function of pressure (MPa) at different temperatures and $2 \mathrm{M} \mathrm{HCl}$. The extraction percentage is inversely proportional to the temperature. The 
results show an Au extraction leaching efficiency of greater than $70 \%$ when a temperature of $40^{\circ} \mathrm{C}$ and $0.34 \mathrm{MPa}$ of pressure were used. Temperature affects the leaching of metals because $\mathrm{HCl}$ begins to decompose at temperatures higher than $53{ }^{\circ} \mathrm{C}$ [19]. On the other hand, at this concentration and $70{ }^{\circ} \mathrm{C}$, not even $30 \%$ recovery is achieved for this metal. Figure $3 \mathrm{~B}$ shows the graph of Au extraction (\%) as a function of pressure and temperature at $4 \mathrm{M} \mathrm{HCl}$. Au extraction was greater than $95 \%$ when a temperature of $40{ }^{\circ} \mathrm{C}$ and a pressure of $0.34 \mathrm{MPa}$ were used.
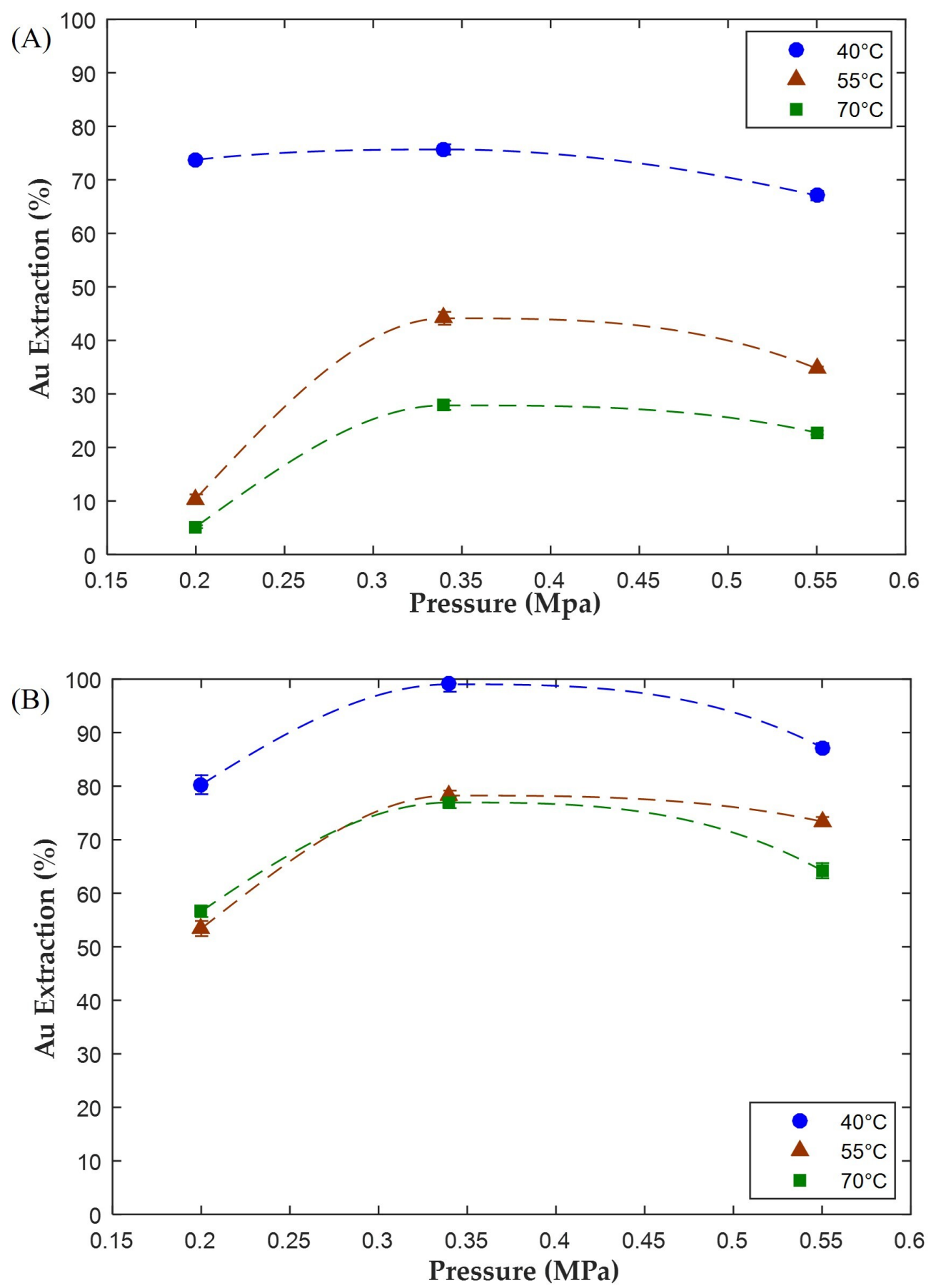

Figure 3. Au extraction (\%) as a function of pressure (MPa), at different temperatures: (A) at $2 \mathrm{M}$ $\mathrm{HCl}$ and (B) $4 \mathrm{M} \mathrm{HCl}$.

The Solubility of $\mathrm{HCl}$ in $\mathrm{H}_{2} \mathrm{O}$ at higher temperatures, by increasing the concentration to about $0.1 \mathrm{M} \mathrm{Cl}^{-}$, is not perceptible; the chloride activity becomes sufficient to stabilize 
the $\left(\mathrm{AuCl}_{2}\right)^{-}$complex. Again, the acidity is shown to be important in maintaining the dissolved gold in the solution. As the solution temperature increases, the gold leaching efficiency also increases within limits. The effect of temperature on gold extraction from the gold sample dissolved in a solution containing $0.5 \% \mathrm{NaOCl}, 5 \% \mathrm{HCl}$ and $1 \mathrm{~g} / \mathrm{L} \mathrm{NaCl}$ was $82 \%$ of the gold was extracted in one hour at $27^{\circ} \mathrm{C}, 95 \%$ at $40{ }^{\circ} \mathrm{C}$ and $90 \%$ at $55^{\circ} \mathrm{C}$. Further increasing the solution temperature to $70^{\circ} \mathrm{C}$ or higher resulted in decreased gold extraction to $67 \%$. This may be due to the greatly decreased chlorine dissolubility in water at a higher temperature, which agrees with the references $[19,20]$.

\subsubsection{Platinum}

Figure 4 shows the effect on platinum leaching when the $\mathrm{HCl}$ concentration $(2 \mathrm{M}$ and $4 \mathrm{M})$, the pressure $(0.2,0.34$ and $0.55 \mathrm{MPa})$ and the temperature $\left(40,55\right.$, and $\left.70{ }^{\circ} \mathrm{C}\right)$ varied. Figure $4 \mathrm{~A}$ shows Pt extraction (\%) as a function of pressure (MPa) at different temperatures and $2 \mathrm{M} \mathrm{HCl}$. Extraction is inversely proportional to temperature, whereby a Pt extraction above $65 \%$ was obtained when using a temperature of $55^{\circ} \mathrm{C}$ and a pressure of $0.34 \mathrm{MPa}$. Temperature affects the leaching of metals because $\mathrm{HCl}$ begins to decompose at temperatures above $53{ }^{\circ} \mathrm{C}[19,20]$. Figure $4 \mathrm{~B}$ shows Pt extraction (\%) as a function of pressure and temperature at $4 \mathrm{M} \mathrm{HCl}$. A Pt extraction above $90 \%$ with a temperature of $40{ }^{\circ} \mathrm{C}$ and $0.34 \mathrm{MPa}$ pressure was obtained. The leaching efficiency was greater at a concentration of $4 \mathrm{M} \mathrm{HCl}$.
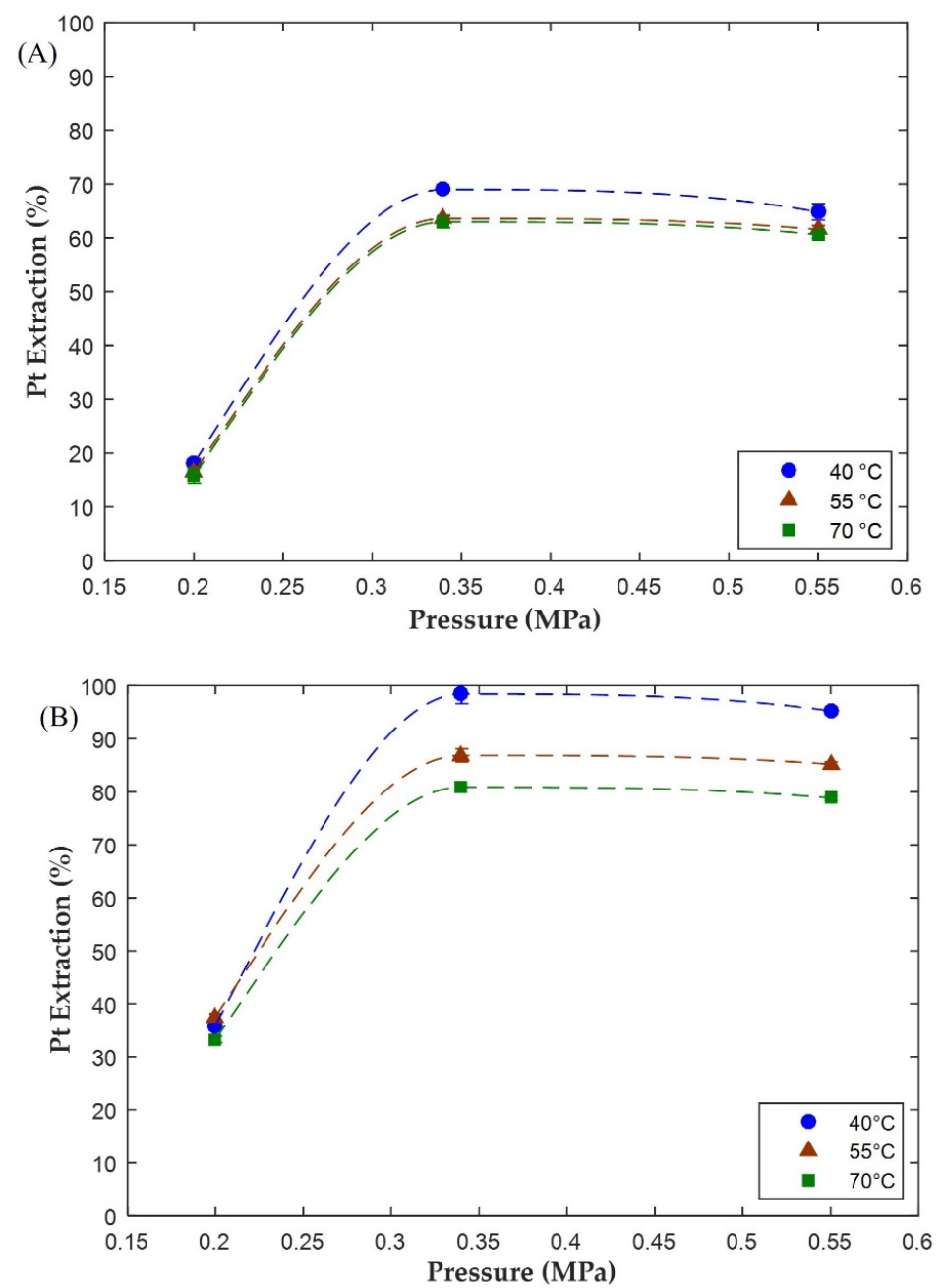

Figure 4. Pt extraction (\%) as a function of pressure (MPa), at different temperatures: (A) at $2 \mathrm{M} \mathrm{HCl}$ and (B) $4 \mathrm{M} \mathrm{HCl}$. 
Table 3 shows the variation in the extraction (\%) for the metals under study, Ag, Au and $\mathrm{Pt}$, as a function of temperature, at a pressure of $0.34 \mathrm{MPa}$ and concentration of $4 \mathrm{M} \mathrm{HCl}$.

Table 3. Extraction (\%) of $\mathrm{Ag}$, $\mathrm{Au}$ and $\mathrm{Pt}=\mathrm{f}$ (Temperature), at $[\mathrm{HCl}]=4 \mathrm{M}$ and $\mathrm{P}=0.34 \mathrm{MPa}$.

\begin{tabular}{cccccccccc}
\hline Time (min) & \multicolumn{3}{c}{ Ag Extraction (\%) } & \multicolumn{3}{c}{ Au Extraction (\%) } & \multicolumn{3}{c}{ Pt Extraction (\%) } \\
\hline & $40{ }^{\circ} \mathrm{C}$ & $55{ }^{\circ} \mathrm{C}$ & $70{ }^{\circ} \mathrm{C}$ & $40{ }^{\circ} \mathrm{C}$ & $55{ }^{\circ} \mathrm{C}$ & $70{ }^{\circ} \mathrm{C}$ & $40{ }^{\circ} \mathrm{C}$ & $55{ }^{\circ} \mathrm{C}$ & $70{ }^{\circ} \mathrm{C}$ \\
\hline 10 & 52.4 & 52.4 & 52.4 & 30.0 & 30.0 & 30.0 & 29.7 & 29.7 & 29.7 \\
20 & 71.3 & 83.5 & 80.0 & 76.3 & 56.9 & 35.2 & 48.1 & 46.8 & 43.3 \\
30 & 84.1 & 85.7 & 81.4 & 81.9 & 73.2 & 53.8 & 56.0 & 54.5 & 54.6 \\
40 & 88.4 & 88.9 & 82.9 & 88.2 & 80.3 & 58.0 & 71.1 & 62.4 & 63.5 \\
60 & 94.5 & 92.8 & 84.9 & 95.9 & 90.7 & 67.7 & 81.3 & 68.6 & 71.7 \\
90 & 97.3 & 94.3 & 86.8 & 98.8 & 96.6 & 77.5 & 94.1 & 76.9 & 78.9 \\
120 & 97.5 & 95.0 & 87.0 & 99.0 & 97.0 & 78.2 & 97.9 & 78.2 & 79.2 \\
\hline
\end{tabular}

\subsection{Thermodynamic Analysis}

Precious metals ( $\mathrm{Ag}$, $\mathrm{Au}$ and $\mathrm{Pt}$ ) have low chemical activity and are difficult to dissolve. The reactions that occur during the leaching of these metals or alloy with sodium chloride, hydrochloric acid, sodium hypochlorite and oxygen are indicated in Equations (1) to (6), considering that they are in metallic form on PCBs.

The leaching of gold occurs in two stages, as shown in Equations (1) and (2):

$$
\begin{gathered}
2 \mathrm{Au}_{(s)}^{\circ}+4 \mathrm{HCl}_{(a q)}+\mathrm{ClO}_{(a q)}^{-}+\mathrm{Cl}_{(a q)}^{-}+\frac{1}{2} \mathrm{O}_{2(g)} \rightarrow 2 \mathrm{AuCl}_{2}^{-}(a q) \\
\mathrm{Cl}_{2(a q)}+2 \mathrm{H}_{2} \mathrm{O} \Delta \mathrm{G}_{40^{\circ} \mathrm{C}}=132.97 \frac{\mathrm{kJ}}{\mathrm{mol}} \\
2 \mathrm{AuCl}_{2(a q)}^{-}+\mathrm{Cl}_{2(a q)} \rightarrow 2 \mathrm{AuCl}_{4(a q)}^{-} \Delta \mathrm{G}_{40^{\circ} \mathrm{C}}=-162.61 \frac{\mathrm{kJ}}{\mathrm{mol}}
\end{gathered}
$$

Silver leaching occurs in two stages, as shown in Equations (3) and (4):

$$
\begin{gathered}
2 \mathrm{Ag}_{(s)}^{\circ}+4 \mathrm{HCl}_{(a q)}+\mathrm{ClO}_{(a q)}^{-}+\mathrm{Cl}_{(a q)}^{-}+\frac{1}{2} \mathrm{O}_{2(g)} \rightarrow 2 \mathrm{AgCl}_{2(a q)}^{-}+\mathrm{Cl}_{2(a q)}+2 \mathrm{H}_{2} \mathrm{O} \Delta \mathrm{G}_{400^{\circ} \mathrm{C}}=14.46 \frac{\mathrm{kJ}}{\mathrm{mol}} \\
2 \mathrm{AgCl}_{2(a q)}^{-}+\mathrm{Cl}_{2(a q)} \rightarrow 2 \mathrm{AgCl}_{3(a q)}^{2-} \Delta \mathrm{G}_{40^{\circ} \mathrm{C}}=-256.36 \frac{\mathrm{kJ}}{\mathrm{mol}}
\end{gathered}
$$

To carry out the dissolution of platinum, the following reactions occur in (5) and (6):

$$
\begin{gathered}
\mathrm{Pt}_{(\mathrm{s})}^{\circ}+4 \mathrm{HCl}_{(a q)}+\mathrm{ClO}_{(a q)}^{-}+\mathrm{Cl}_{(a q)}^{-}+1 / 2 \mathrm{O}_{2(g)} \rightarrow \mathrm{PtCl}_{4(a q)}^{2-}+\mathrm{Cl}_{2(a q)}+2 \mathrm{H}_{2} \mathrm{O} \Delta \mathrm{G}_{40}{ }^{\circ} \mathrm{C}=86.61 \frac{\mathrm{kJ}}{\mathrm{mol}} \\
\mathrm{PtCl}_{4(a q)}^{2-}+\mathrm{Cl}_{2(a q)} \rightarrow \mathrm{PtCl}_{6(a q)}^{2-} \Delta \mathrm{G}_{40}{ }^{\circ} \mathrm{C}=-119.39 \frac{\mathrm{kJ}}{\mathrm{mol}}
\end{gathered}
$$

Figures 5-7 show Eh-pH Pourbaix diagrams, which were constructed for each metalelectrolyte system using HSC 6.0 software with the conditions of $40{ }^{\circ} \mathrm{C}, 0.34 \mathrm{MPa}$ and the corresponding metal concentration. The two indicated points represent the species present at the different molarities of $\mathrm{HCl}$ used in the experimental tests, according to REDOX potential $(\mathrm{Eh})$ and $\mathrm{pH}(2 \mathrm{M}(\mathrm{Eh}=0.8 \mathrm{v}, \mathrm{pH}=-1)$ and $4 \mathrm{M}(\mathrm{Eh}=1.3 \mathrm{v}, \mathrm{pH}=-1.7))$. Figure 5 shows the species diagram for the $\mathrm{Ag}-\mathrm{Cl}-\mathrm{H}_{2} \mathrm{O}$ system, wherein the location of the points suggests the existing species in the solution is aqueous silver chloride $\left(\mathrm{AgCl}_{3}{ }^{2-}\right)$. With $\mathrm{HCl}$ at $4 \mathrm{M}$, there is a greater area of stability, and the leaching efficiency is above $97 \%$. 


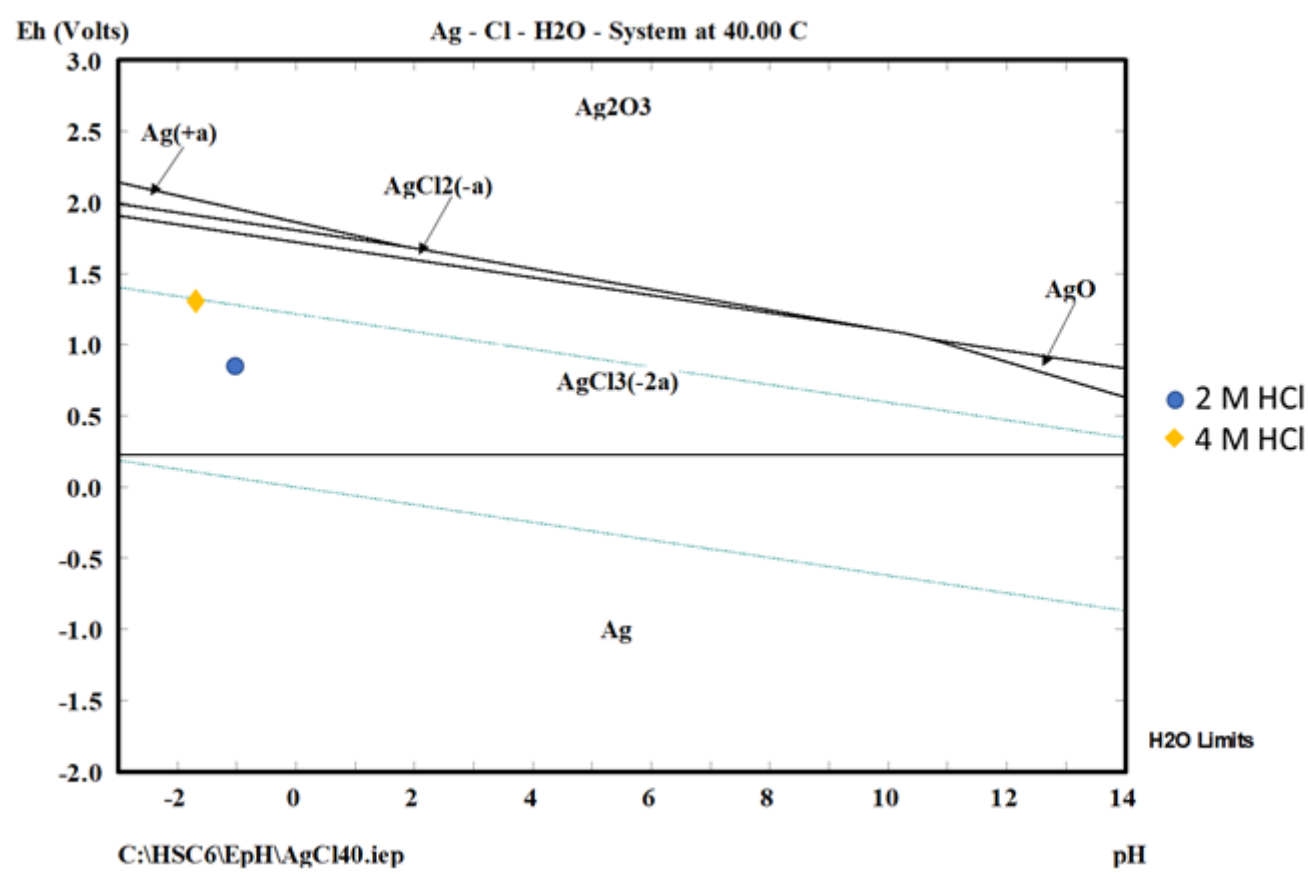

Figure 5. Eh-pH diagram for the $\mathrm{Ag}-\mathrm{Cl}-\mathrm{H}_{2} \mathrm{O}$ system at $[\mathrm{Ag}]=0.00048 \mathrm{M}, 40{ }^{\circ} \mathrm{C}$ and $0.34 \mathrm{MPa}$.

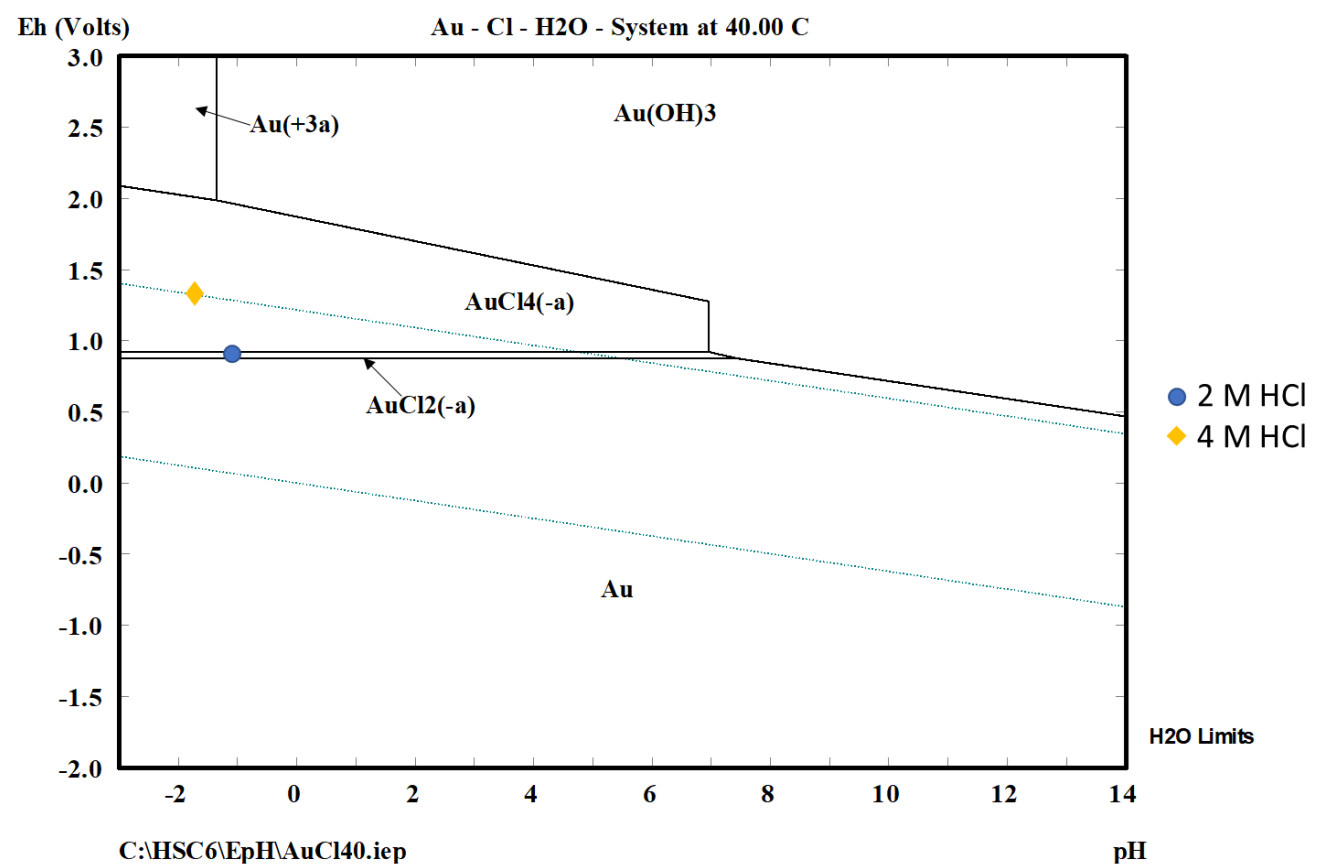

Figure 6. Eh- $\mathrm{pH}$ diagram for the $\mathrm{Au}-\mathrm{Cl}-\mathrm{H}_{2} \mathrm{O}$ system, with $[\mathrm{Au}]=0.00036 \mathrm{M}, 40{ }^{\circ} \mathrm{C}$ and $0.34 \mathrm{MPa}$. 


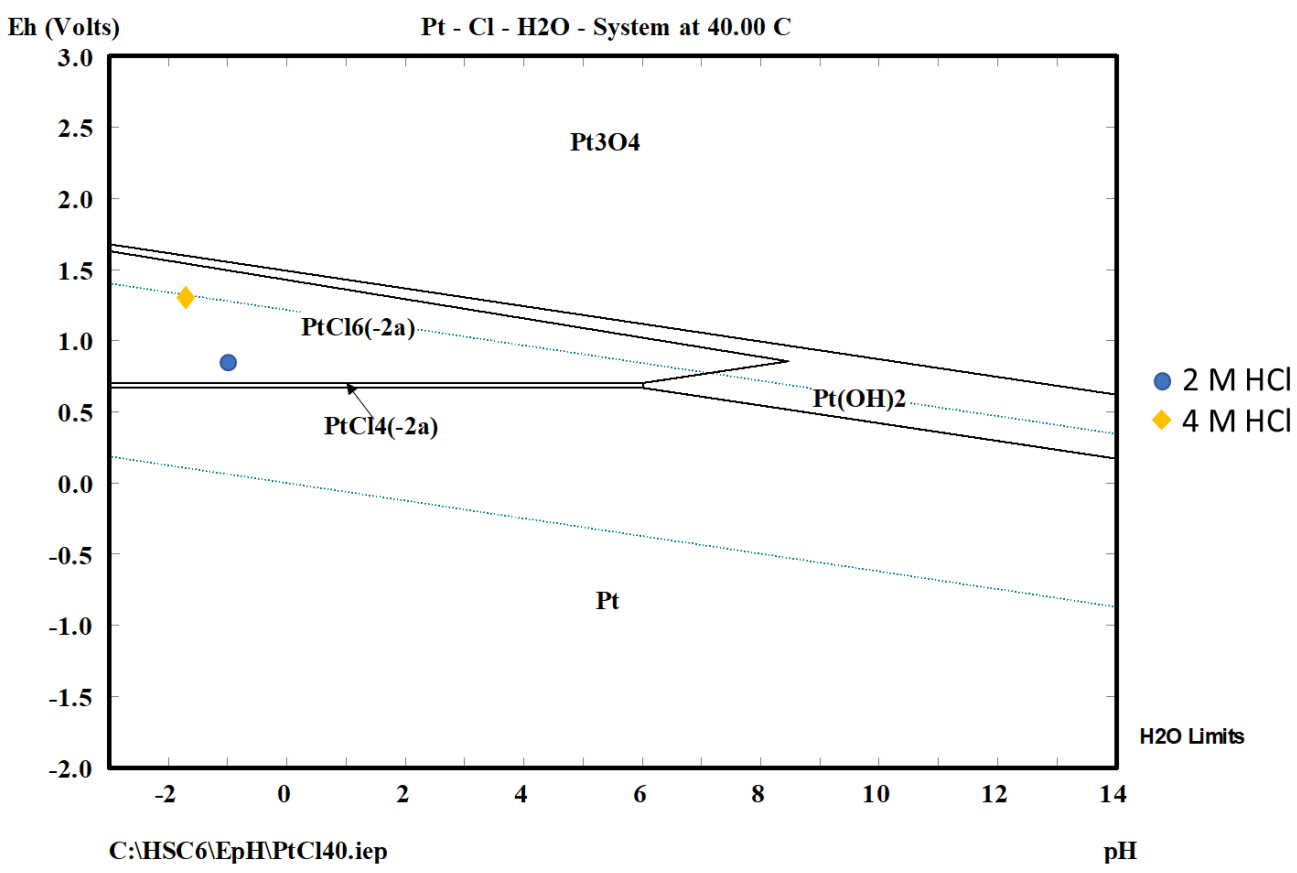

Figure 7. Eh-pH diagram for the $\mathrm{Pt}-\mathrm{Cl}-\mathrm{H}_{2} \mathrm{O}$ system with $[\mathrm{Pt}]=0.000025 \mathrm{M}, 40{ }^{\circ} \mathrm{C}$ and $0.34 \mathrm{MPa}$.

Figure 6 shows the species diagram for the $\mathrm{Au}-\mathrm{Cl}-\mathrm{H}_{2} \mathrm{O}$ system, wherein the locations of the points suggest the existing species in the solution is aqueous gold chloride $\left(\mathrm{AuCl}_{4}{ }^{-}\right)$. However, with $\mathrm{HCl}$ at $4 \mathrm{M}$, based on the greater species stability, the extraction efficiency is above $95 \%$.

Figure 7 shows the species diagram for the $\mathrm{Pt}-\mathrm{Cl}-\mathrm{H}_{2} \mathrm{O}$ system, wherein the locations of the points suggest the existing species in the solution is the aqueous chloride-platinum complex. With a $\mathrm{pH}$ lower than 7 and a redox potential above 0.7 , the soluble complex $\left(\mathrm{PtCl}_{6}{ }^{2-}\right)$ is stable. However, with $\mathrm{HCl}$ at $4 \mathrm{M}$, the area of stability is greater since the leaching efficiency of platinum in these conditions was greater than $98 \%$.

\subsection{Study of PCBs Material from the Leaching Tests by SEM-EDS}

Figure 8 shows the SEM micrograph and microanalysis of the PCBs material after pre-treatment with $\mathrm{H}_{2} \mathrm{SO}_{4}$ and before leaching with $\mathrm{HCl}$ for the recovery of $\mathrm{Ag}, \mathrm{Au}$ and $\mathrm{Pt}$. Results show that the morphology of the material is very diverse and contains elements such as $\mathrm{Au}, \mathrm{Pd}, \mathrm{W}, \mathrm{Ti}, \mathrm{Sn}$ and $\mathrm{Br}$. It should be noted that the presence of other elements is due to the PCBs base composition; for example, Br presence is caused by the Brominated flame retardants (BFRs) used in the plastic housings of electronic equipment and in PCBs to prevent flammability [21].

Figure 9 shows the SEM micrograph and microanalysis of the sample leached with $4 \mathrm{M} \mathrm{HCl}$ at $0.34 \mathrm{MPa}$ and $40^{\circ} \mathrm{C}$, from which the highest percentage of precious metals was extracted. Additionally, the non-evidence of the metals $\mathrm{Ag}$, $\mathrm{Au}$ and $\mathrm{Pt}$ were confirmed, since they were leached by means of $\mathrm{HCl}, \mathrm{NaClO}$ and $\mathrm{O}_{2}$. The morphology of the material is very diverse, and the identified elements were $\mathrm{Al}, \mathrm{Br}, \mathrm{Ti}, \mathrm{Mg}$, Si and $\mathrm{Cl}$; the latter is present in the reagents used for leaching. It should be noted that the presence of the other elements is due to the PCBs base composition as mentioned earlier, for example, Ba, which is used to protect users from radiation. 

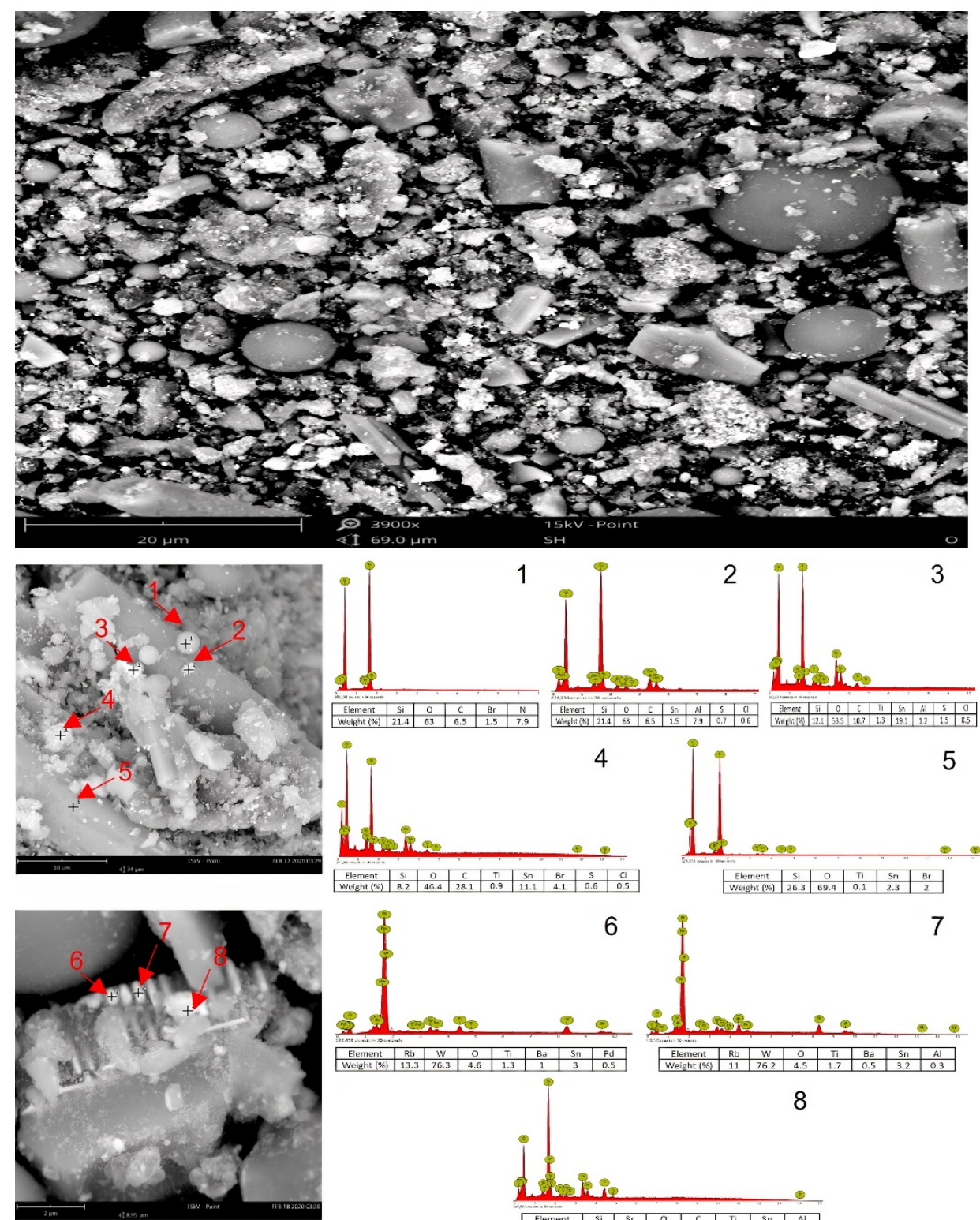

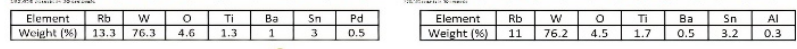
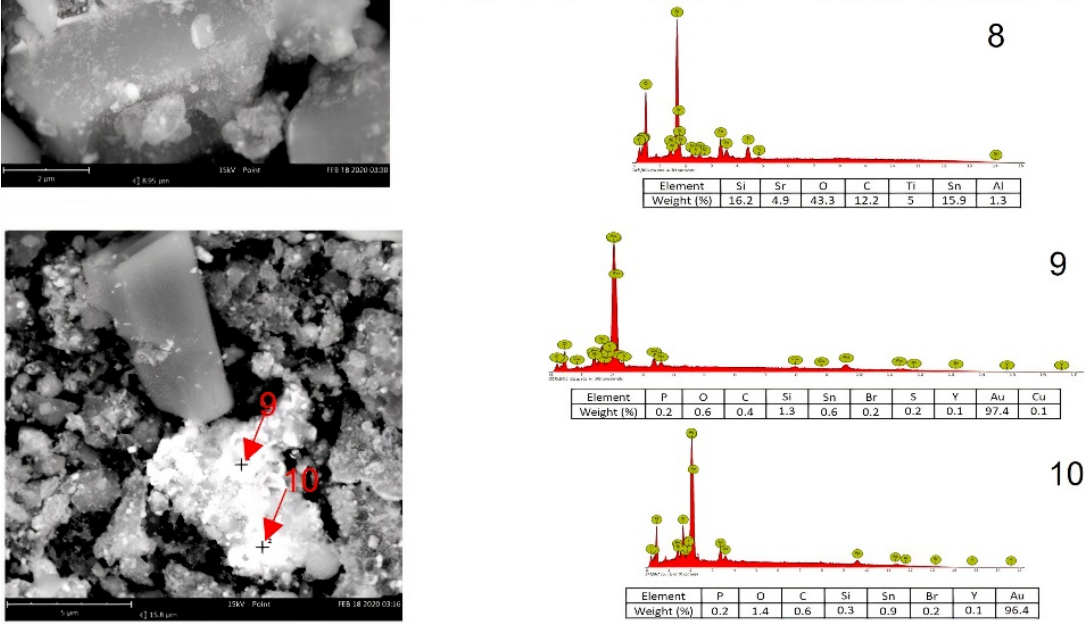

Figure 8. Scanning electron microscopy (SEM-EDS) images, micrograph and microanalysis of the PCBs sample before $\mathrm{HCl}$ leaching. The numbers (1-10) mean punctual microanalysis. 


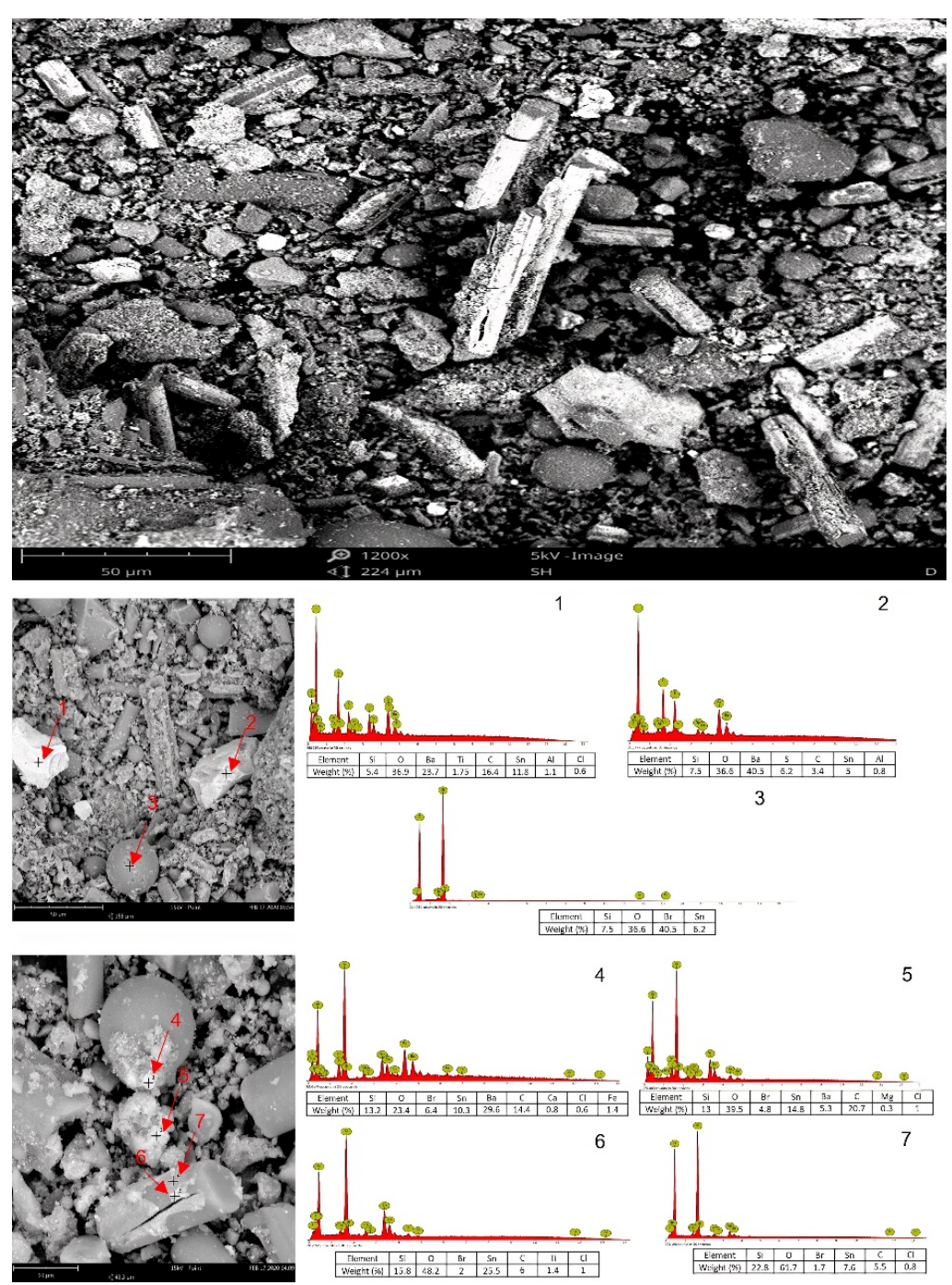

Figure 9. Scanning electron microscopy (SEM-EDS) images, micrograph and microanalysis of the PCBs sample leached with $4 \mathrm{M} \mathrm{HCl}$ at $0.34 \mathrm{MPa}$ and $40{ }^{\circ} \mathrm{C}$. The numbers (1-7) mean punctual microanalysis.

\section{Discussion}

Gold and platinum, as precious metals, have a low chemical activity, showing a high resistance to dissolution. A chlorination leaching method is directly used to extract $\mathrm{Pt}$, $\mathrm{Ag}$ and $\mathrm{Au}$ from waste PCBs, in which the $\mathrm{Pt}$ and $\mathrm{Au}$ are chlorinated and transferred to acid soluble $\mathrm{PtCl}_{6}{ }^{2-}, \mathrm{AgCl}_{3}{ }^{2-}$ and $\mathrm{AuCl}_{4}{ }^{-}$through Equations (1)-(6) in a solution of $\mathrm{NaCl}-\mathrm{HCl}-\mathrm{NaClO}$. The stability Eh-pH diagrams for systems of $\mathrm{Ag}-\mathrm{Cl}-\mathrm{H}_{2} \mathrm{O}, \mathrm{Au}-\mathrm{Cl}-\mathrm{H}_{2} \mathrm{O}$ and $\mathrm{Pt}-\mathrm{Cl}-\mathrm{H}_{2} \mathrm{O}$ at $40{ }^{\circ} \mathrm{C}$ are presented in Figures 5-7, respectively. The potential for Ag leachable varies from $0.2 \mathrm{~V}$ to $1.9 \mathrm{~V}$ over a wide $\mathrm{pH}$ range, Au leachable ranges from $0.96 \mathrm{~V}$ to $2.12 \mathrm{~V}$ with the $\mathrm{pH}$ from -2 to 7.05 , as seen in Figure 6, and that for Pt extends from $0.65 \mathrm{~V}$ to $1.65 \mathrm{~V}$ with the $\mathrm{pH}$ from -2 to 7.7 , as shown in Figure 7. To achieve these high potentials for obtaining high leaching efficiency of $\mathrm{Au}$ and $\mathrm{Pt}$, much $\mathrm{NaClO}$ should be employed in the leaching process. However, it causes the utilization efficiency of chlorine to be decreased due to the higher emission of $\mathrm{Cl}_{2}$ during the leaching process.

SEM micrographs of the raw material before leaching with hydrochloric acid show that the morphology is very diverse. The microanalysis shows that it contains several chemical elements: $\mathrm{Au}, \mathrm{Pd}, \mathrm{Rb}, \mathrm{W}, \mathrm{Ti}, \mathrm{Sn}$ and $\mathrm{Br}$, of which $\mathrm{Au}$ and $\mathrm{Pd}$ were of interest in this research, and with the microanalysis, it is shown that there are particles with these metals of interest. Likewise, in the micrograph of the leached solid where a higher percentage of extraction of 
the metals of interest was obtained, it is observed that the morphology of this material is very diverse, and the particles analyzed by microanalysis contain $\mathrm{Ba}, \mathrm{Br}, \mathrm{Cl}, \mathrm{O}, \mathrm{Ti}$, $\mathrm{Sn}$ and $\mathrm{Si}$, of which none were an item of interest.

In both micrographs of the material, before and after the leaching of precious metals with hydrochloric acid, spherical and cylindrical particles can be observed. By microanalysis with EDS, it was determined that its elemental composition is $\mathrm{Si}, \mathrm{O}, \mathrm{C}, \mathrm{Sn}, \mathrm{Br}$ and N; these elements form the basis of printed circuit boards. In the leaching of PCBs with the help of chlorine gas in aqueous medium, a high recovery of gold could be obtained, but chlorine gas causes serious corrosion problems of the equipment. [17]. Based on the results of this research, it is possible to take advantage of strongly oxidizing hypochlorite species, which can be generated by adding inorganic hypochlorite salts to a solution [18]. A chlorination leaching process using a $\mathrm{NaCl}-\mathrm{HCl}-\mathrm{NaClO}$ mixture has greater advantages, including faster gold leaching efficiency, reaching up to $95 \%$ in $1 \mathrm{~h}$ and $99 \%$ in $2 \mathrm{~h}$. However, the leaching efficiency of platinum is low under optimal conditions favoring the leaching of Au, which causes a considerable amount of platinum to be distributed in the leaching residue and, consequently, the leaching efficiency of platinum can be difficult to increase. The temperature has an adverse effect on platinum extraction because with increasing temperature, platinum extraction decreases, which is in accordance with the references $[19,20]$. At a temperature of $70{ }^{\circ} \mathrm{C}$, less metal extraction was obtained compared to lower temperatures, probably because of the significant reduction in the dissolubility of chlorine in water at high temperatures. The extraction of $\mathrm{Au}$ and $\mathrm{Ag}$ decreased with the increase in pressure to $0.55 \mathrm{MPa}$, explained by the excessive amount of $\mathrm{H}_{2} \mathrm{O}$ generated. Therefore, the chlorine gas formation was reduced due to the transition of hydrochloric acid and chlorine, resulting in a decrease in metal extraction.

\section{Conclusions}

The results of this research revealed that more than $97 \% \mathrm{Ag}, 99 \% \mathrm{Au}$ and $98 \% \mathrm{Pt}$ can be leached from the PCBs by an $\mathrm{NaCl}-\mathrm{HCl}-\mathrm{NaClO}$ mixed solution in $2 \mathrm{~h}$, at pressure of $0.34 \mathrm{MPa}$, a temperature of $40^{\circ} \mathrm{C}, \mathrm{HCl}$ at $4 \mathrm{M}$ and $\mathrm{NaClO}$ at $0.067 \mathrm{M}$.

The concentration of $\mathrm{HCl}$ and the temperature significantly affect the leaching of $\mathrm{Au}$ and $\mathrm{Pt}$, as better results are obtained at a concentration of $4 \mathrm{M}$ and a temperature of $40^{\circ} \mathrm{C}$. Based on the Pourbaix diagram of the $\mathrm{Pt}-\mathrm{Cl}-\mathrm{H}_{2} \mathrm{O}$ system, at $2 \mathrm{M} \mathrm{HCl}$, $\mathrm{Pt}$ dissolves less effectively and, in the Pourbaix diagram of the $\mathrm{Ag}-\mathrm{Cl}-\mathrm{H}_{2} \mathrm{O}$ system, if this metal covers $\mathrm{Ag}$ or $\mathrm{Au}$ (or some other metal), it is not able to leach. Instead, at a $\mathrm{HCl}$ concentration of $4 \mathrm{M}$, this metal remains as an aqueous chloride and the percentage of extraction of Ag is higher.

Under the experimental conditions, the Eh-pH diagrams confirmed extraction of these metals, mainly because they ground thermodynamically favorable conditions for metal leaching.

According to the results of the laboratory tests, this research shows that it is feasible to recover precious metals from PCBs by leaching with hydrochloric acid and sodium hypochlorite at moderate temperatures and pressures. Recovery of major beneficial metals, $\mathrm{Ag}$, Au and $\mathrm{Pt}$, followed by production of minimal waste materials with known character, represent a great advantage for presenting a technological route, which is of the highest importance for the lower operating capacities. Further analysis of the process economy could give a more comprehensive overview if such a process represents a promising alternative for the present status dominated by the pyrometallurgical sector.

Author Contributions: Conceptualization, G.M.-B. and J.L.V.-G.; formal analysis, G.M.-B. and F.A.M.-Z.; investigation, G.M.-B., J.L.V.-G., and A.G.-A.; methodology, G.M.-B., J.L.V.-G., A.G.-A., and A.d.J.R.-D.; project administration, J.L.V.-G. and R.V.-F.; resources, M.A.E.-R., R.V.-F., and J.L.V.-G.; data curation, A.G.-A. and F.A.M.-Z.; formal analysis, G.M.-B. and J.L.V.-G.; supervision, J.L.V.-G. and A.G.-A.; validation, G.M.-B. and M.A.E.-R.; writing-original draft, G.M.-B.; writing-review and editing, J.L.V.-G., A.G.-A., A.d.J.R.-D., and F.A.M.-Z. All authors have read and agreed to the published version of the manuscript.

Funding: This research was funded by LANGEM, Grant Number 294889, National Laboratory of Geochemistry and Mineralogy in México and CONACYT (National Council of Science and Technology) for graduate scholarship of one author (G.M.-B.). 
Institutional Review Board Statement: Not applicable.

Informed Consent Statement: Not applicable.

Data Availability Statement: Not applicable.

Acknowledgments: Thanks to the Engineering Division, Chemical Engineering and Metallurgy Department, and the Geology Department of the University of Sonora, and Retroworks de México for their support in this research.

Conflicts of Interest: The authors declare no conflict of interest. The funders had no role in the design of the study; in the collection, analyses, or interpretation of data; in the writing of the manuscript; or in the decision to publish the results.

Sample Availability: Not available.

\section{References}

1. Tuncuk, A.; Stazi, V.; Akcil, A.; Yazici, E.Y.; Deveci, H. Aqueous metal recovery techniques from e-scrap: Hydrometallurgy in recycling. Miner. Eng. 2012, 25, 28-37. [CrossRef]

2. Petter, P.M.H.; Veit, H.M.; Bernardes, A.M. Evaluation of gold and silver leaching from printed circuit board of cellphones. Waste Manag. 2014, 34, 475-482. [CrossRef] [PubMed]

3. Evangelopoulos, P.; Persson, H.; Kantarelis, E.; Yang, W. Performance analysis and fate of bromine in a single screw reactor for pyrolysis of waste electrical and electronic equipment (WEEE). Process. Saf. Environ. Prot. 2020, 143, 313-321. [CrossRef]

4. Vats, M.C.; Singh, S.K. Assessment of gold and silver in assorted mobile phone printed circuit boards (PCBs): Original article. Waste Manag. 2015, 45, 280-288. [CrossRef] [PubMed]

5. Widmer, R.; Oswald-Krapf, H.; Sinha-Khetriwal, D.; Schnellmann, M.; Böni, H. Global perspectives on e-waste. Environ. Impact Assess. Rev. 2005, 25, 436-458. [CrossRef]

6. Wu, Z.; Yuan, W.; Li, J.; Wang, X.; Liu, L.; Wang, J. A critical review on the recycling of copper and precious metals from waste printed circuit boards using hydrometallurgy. Front. Environ. Sci. Eng. 2017, 11, 8. [CrossRef]

7. Duan, H.; Li, J.; Liu, Y.; Yamazaki, N.; Jiang, W. Characterization and Inventory of PCDD/Fs and PBDD/Fs Emissions from the Incineration of Waste Printed Circuit Board. Environ. Sci. Technol. 2011, 45, 6322-6328. [CrossRef] [PubMed]

8. Duan, H.; Li, J.; Liu, Y.; Yamazaki, N.; Jiang, W. Characterizing the emission of chlorinated/brominated dibenzo-p-dioxins and furans from low-temperature thermal processing of waste printed circuit board. Environ. Pollut. 2012, 161, 185-191. [CrossRef] [PubMed]

9. Hall, W.J.; Williams, P.T. Pyrolysis of brominated feedstock plastic in a fluidised bed reactor. J. Anal. Appl. Pyrolysis 2006, 77, 75-82. [CrossRef]

10. Wen, S.; Yang, F.; Li, J.G.; Gong, Y.; Zhang, X.L.; Hui, Y.; Wu, Y.N.; Zhao, Y.F.; Xu, Y. Polychlorinated dibenzo-p-dioxin and dibenzofurans (PCDD/Fs), polybrominated diphenyl ethers (PBDEs), and polychlorinated biphenyls (PCBs) monitored by tree bark in an E-waste recycling area. Chemosphere 2009, 74, 981-987. [CrossRef] [PubMed]

11. Khaliq, A.; Rhamdhani, M.A.; Brooks, G.; Masood, S. Metal Extraction Processes for Electronic Waste and Existing Industrial Routes: A Review and Australian Perspective. Resources 2014, 3, 152-179. [CrossRef]

12. Xiu, F.R.; Zhang, F.S. Electrokinetic recovery of Cd, Cr, As, Ni, Zn and Mn from waste printed circuit boards: Effect of assisting agents. J. Hazard. Mater. 2009, 170, 191-196. [CrossRef] [PubMed]

13. Gámez, S.; Garcés, K.; de la Torre, E.; Guevara, A. Precious metals recovery from waste printed circuit boards using thiosulfate leaching and ion exchange resin. Hydrometallurgy 2019, 186, 1-11. [CrossRef]

14. Birloaga, I.; De Michelis, I.; Ferella, F.; Buzatu, M.; Vegliò, F. Study on the influence of various factors in the hydrometallurgical processing of waste printed circuit boards for copper and gold recovery. Waste Manag. 2013, 33, 935-941. [CrossRef] [PubMed]

15. Jadhav, U.; Hocheng, H. Hydrometallurgical Recovery of Metals from Large Printed Circuit Board Pieces. Sci. Rep. 2015, 5, 14574. [CrossRef] [PubMed]

16. Torres, R.; Lapidus, G.T. Copper leaching from electronic waste for the improvement of gold recycling. Waste Manag. 2016, 57, 131-139. [CrossRef] [PubMed]

17. Lei, L.I.; Song, W.; GuoDong, W.; Heng, W.; ShiDing, W. Extraction of platinum and gold from copper anode slimes by a process of chlorinating roasting first and chlorinating leaching followed. J. Min. Metall. Sect. B: Metall. 2020, 56, $193-202$.

18. Marsden, J.; House, I. The Chemistry of Gold Extraction; Society for Mining, Metallurgy, and Exploration: Littleton, CO, USA, 2006.

19. Fuerstenau, M.C. Advances in Gold and Silver Processing. In Proceedings of the Symposium at GOLDTech 4, Reno, NV, USA, 10-12 September 1990; Society for Mining, Metallurgy, and Exploration: Littleton, CO, USA, 1990.

20. Yen, W.T.; Pindred, R.A.; Lam, M.P. Hypochlorite leaching of gold ore. In Proceedings of the Advances in Gold and Silver Processing, Reno, NV, USA, 10-12 September 1990; pp. 67-74.

21. Zhou, X.; Guo, J.; Lin, K.; Huang, K.; Deng, J. Leaching characteristics of heavy metals and brominated flame retardants from waste printed circuit boards. J. Hazard. Mater. 2013, 246, 96-102. [CrossRef] [PubMed] 